\title{
High acceptance rate of anal pap screening despite limited knowledge about anal dysplasia among HIV+ MSM
}

\author{
Julia Seay ${ }^{1}$, Timothy Sadiq ${ }^{2}$, Katya Roytburd', Prema Menezes ${ }^{1,3}$, E Byrd Quinlivan 1,3,4* \\ From $12^{\text {th }}$ International Conference on Malignancies in AIDS and Other Acquired Immunodeficiencies \\ (ICMAOI) \\ Bethesda, MD, USA. 26-27 April, 2010
}

\section{Background}

Anal cancer in the general population is more prevalent in women, but in most HIV populations, MSM have the highest risk. Data suggest that screening can prevent invasive carcinoma. Use of routine cervical pap smears resulted in an $80 \%$ reduction in cervical cancer rates. The current study examines the effectiveness of a clinical intervention designed to increase anal dysplasia education, screening, and treatment for HIV+ MSM.

\section{Methods}

To assess anal dysplasia knowledge, sexual history/behavior, and attitudes about health care, a convenience sample of HIV+ MSM ( $\geq 18$ years, English-speaking) being seen for routine care were asked to complete a questionnaire. The questionnaire assessed anal dysplasia knowledge and acceptance of screening anal pap utilizing a 5-point Likert-scale. Subjects were categorized as having anal dysplasia knowledge and accepting of anal pap smear if they answered "agree" or "strongly agree." A chi-square analysis was conducted to determine whether those with anal dysplasia knowledge significantly differed from those who did not in terms of anal pap screening. Clinical information was abstracted from medical records.

\section{Results}

Of 142 subjects, 56\% were Caucasian, 39\% were African American, and 5\% were of other ethnicities with a mean age of 44 years (SD 10.74 years) and eighth grade or

\footnotetext{
*Correspondence: ebq@med.unc.edu

${ }^{1}$ Center for Infectious Diseases, University of North Carolina at Chapel Hill, Chapel Hill, NC, USA

Full list of author information is available at the end of the article
}

higher reading level (88\%). Most (92\%) subjects were on ART with median HIV RNA $<48$ copies per $\mathrm{mL}$ and median CD4 534 cells/UL. Although less than half (39\%) of the participants felt their current knowledge of anal dysplasia was sufficient to make decisions about detection and treatment, acceptance of anal pap smear screening was close to universal (93\%). One-third of subjects (50) had undergone anal pap testing and of these, $44 \%$ had dysplasia. Knowledge of dysplasia was not significantly correlated with anal pap screening $(\mathrm{p}=.37)$.

\section{Conclusions}

We found a high acceptance rate of anal pap smear despite low rates of knowledge about anal dysplasia. Importantly, anal dysplasia knowledge did not differ between patients who had been previously screened for anal dysplasia and those who had not. These results suggest that the clinical intervention to increase anal dysplasia screening and treatment must also focus on patient education and awareness. The high acceptance rate of the anal pap test indicates that, if implemented effectively, anal dysplasia screening should be well received by patients.
Acknowledgements

This article has been published as part of Infectious Agents and Cancer Volume 5 Supplement 1, 2010: Proceedings of the $12^{\text {th }}$ International Conference on Malignancies in AIDS and Other Acquired Immunodeficiencies (ICMAOI). The full contents of the supplement are available online at http://www.biomedcentral.com/1750-9378/5?issue=S1

\section{Author details}

${ }^{1}$ Center for Infectious Diseases, University of North Carolina at Chapel Hill, Chapel Hill, NC, USA. ²Department of Gl Surgery, University of North Carolina at Chapel Hill, Chapel Hill, NC, USA. ${ }^{3}$ Center for AIDS Research, University of 
Published: 11 October 2010

doi:10.1186/1750-9378-5-S1-A31

Cite this article as: Seay et al:: High acceptance rate of anal pap

screening despite limited knowledge about anal dysplasia among HIV+

MSM. Infectious Agents and Cancer 2010 5(Suppl 1):A31.

Submit your next manuscript to BioMed Central and take full advantage of:

- Convenient online submission

- Thorough peer review

- No space constraints or color figure charges

- Immediate publication on acceptance

- Inclusion in PubMed, CAS, Scopus and Google Scholar

- Research which is freely available for redistribution

Submit your manuscript at www.biomedcentral.com/submit 